Review paper

\title{
Main problems in natural seed regeneration of pedunculate oak (Quercus robur L.) stands in Ukraine
}

\author{
Maksym Rumiantsev ${ }^{1}$, Volodymyr Luk'yanets ${ }^{1}$, Sergiy \\ Musienko ${ }^{2}$, Andriy Mostepanyuk ${ }^{3}$ and Iryna Obolonyk ${ }^{1 *}$
}

\begin{abstract}
Rumiantsev, M., Luk'yanets, V., Musienko, S., Mostepanyuk, A., Obolonyk, I. 2018. Main problems in natural seed regeneration of pedunculate oak (Quercus robur L.) stands in Ukraine. - Forestry Studies | Metsanduslikud Uurimused 69, 7-23, ISSN 1406-9954. Journal homepage: http://mi.emu.ee/forestry.studies
\end{abstract}

\begin{abstract}
The literature review article sums up research experiences in natural seed regeneration in oak forests. In the past, the natural habitat for pedunculate oak (Quercus robur L.) was considerably wider than now. The downward trend in the area of oak stands is observed both in Ukraine and other European countries. In Ukraine, the area of natural oak stands of seed origin is decreasing by 2.0 thousand hectares each year. The most significant environmental factor in the emergence and normal growth of young oaks of seed origin is the light amount, which should reach at least $20 \%$ of the full sunlight. In addition to the light, the main factors contributing to the emergence of oak seedlings under forest canopies and in cutting areas are the oak fruiting and the litter and soil moisture. On the contrary, the excessive development of forest live cover with sedge and cereal vegetation, root competition from the parent trees, and a dense undergrowth were the hindering factors. In the forests of Ukraine, the largest number of natural seed reproduction of oak (more than 100 thousand stems ha-1) after the harvest year was recorded under the canopy of mature and overmature oak forests with a stocking of 0.6-0.7 and with 70 oaks in the stand species composition, growing in conditions of fresh and moist oak forests of Polissya and Forest-Steppe zones. Scientific and methodical guidelines for using natural reproduction of valuable species during the natural seed regeneration of oak stands were improved.
\end{abstract}

Key words: seedling, sampling, natural reproduction, cut-over area, crown closure.

Authors` address: ${ }^{1}$ Ukrainian Research Institute of Forestry and Forest Melioration named after G.M. Vysotsky, Pushkinska str. 86, 61024 Kharkiv, Ukraine; ${ }^{2}$ O.M. Beketov National University of Urban Economy in Kharkiv, Marshal Bazhanov str. 17, 61002 Kharkiv, Ukraine; ${ }^{3}$ State Enterprise "Kharkiv Forest Research Station", 61108 Kharkiv, Ukraine; "e-mail: obolonik@uriffm.org.ua

\section{Introduction}

The natural range of pedunculate oak (Quercus robur L.) covers the entire Western Europe with the exception of most of the Iberian Peninsula and Scandinavia, Central Europe, Turkey, the Republics of Be- larus, Lithuania, Latvia, Estonia, Ukraine and much of the territory of the European part of Russia (Didenko \& Vlasov, 2006). In Ukraine, the area of oak forests exceeds 1.7 million hectares (Figure 1; Kopiy et al., 2017). 


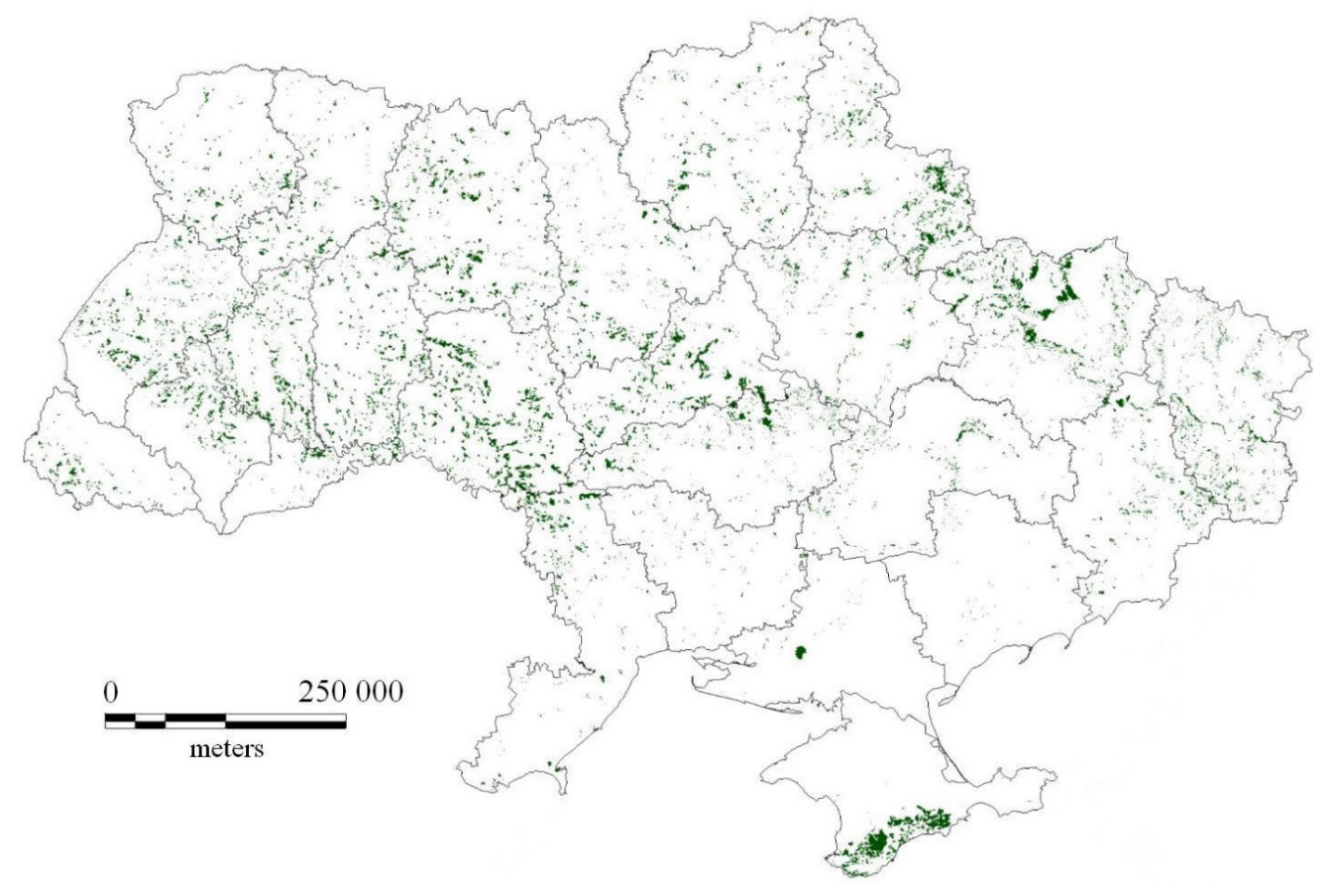

Figure 1. Oak stands locations in Ukraine.

In the past, the area occupied by oaks was considerably wider than now. Under the influence of adverse factors, as well as due to human activity, it has significantly decreased. In many European countries, oak forests are gradually replaced by mixed deciduous ones (Götmark \& Kiffer, 2014; Finnström, 2016; Kopiy et al., 2017). During the $16^{\text {th }}-19^{\text {th }}$ centuries, Ukrainian oak forests were massively destroyed. Intensive cutting has led to a significant reduction in the area of highly productive oak stands (Kopiy et al., 2017). The results of the analysis of forest management materials show that during the period of 2000-2010 the area of oak forests of natural seed origin decreased by 20.5 thousand hectares, or by $6 \%$. Every year, $0.6 \%$ or about 2.0 thousand hectares of the most productive, most resistant and most valuable oak forests are lost.

One of the important aspects of the management in oak forests during their regeneration, both in Ukraine and in oth- er European countries, is the use of natural reproduction of oak and other valuable species because the stands of natural seed origin are biologically more resistant to negative environmental factors, diseases and pests. The stands are longer-lived; they reach a greater height and have a better quality of wood in comparison with coppice stands and planted forests. Also, they are centers of the gene resource for local populations of pedunculate oak. Natural oak reproduction consists of young oak seedlings of natural seed origin. Identification of peculiarities of the advance reproduction as well as analysis of its quantity and quality will promote the development of appropriate activities for the seed regeneration of high-yielding, biologically resistant natural oak stands. It will allow predicting their further development and preserving genetic potential. This problem becomes significant due to the current gradual warming and aridization of climate and the dynamic increase in the area 
of the nature reserve fund, the majority of which are tree stands with oak in their composition (Dobrowolska, 2008; Dobrovolný, 2014; Annighöfer et al., 2015; Tkach et al., 2017).

The absence of the advance growth of pedunculate oak under the canopy of mixed oak-deciduous forests or the low number of it in different countries of Europe is evidenced by many scientific studies (Bobiec et al., 2011; Ikauniece et al., 2012; Götmark \& Kiffer, 2014; Vizoso-Arribe et al., 2014; Annighöfer et al., 2015; Finnström, 2016; Laurent et al., 2017). The lack of oak natural seed reproduction is a serious problem both for forestry and for environmental protection, as it can lead to profound changes in the forest structure (Ortmann-Ajkai et al., 2017).

Ukrainian oak forests are the subject of intensive forest management. The increased use of clearcutting without consideration and preservation of natural reproduction of pedunculate oak under a forest canopy and on cut-over areas has resulted in the prevailing of planted oak forest stands in a large territory of Ukraine. Some forest plantations were established in sites with good natural reproduction (Hensiruk, 2002). The area of natural oak stands decreases steadily, which indicates a reduction of the potential for natural regeneration and a disruption of the ontogenesis cycle. This will cause the loss of biological diversity of pedunculate oak stands and intensify the processes of their degradation in the near future (Tkach et al., 1996).

In Ukraine, the overwhelming majority of oak forests have a vegetative origin, with multiple generations. Their productivity and biological sustainability are low. Each new generation of a coppice that arises from the same root system shows increasing signs of aging, which affects the growing capacity, disease resistance, lifetime, and wood quality (Pyatnitskiy, 1968). Replacing such forests with the stands of seed origin is an important task for forest management.
The purpose of this study was to sum up the experience of Ukrainian and foreign scientists in the natural seed regeneration of oak stands and to identify factors contributing to or inhibiting the emergence and development of advance growth of economically valuable species under the canopy of stands and in cut-over areas. The study also was aimed at providing recommendations concerning a range of forestry activities and silvicultural treatments facilitating oak seed natural regeneration.

\section{Materials and Methods}

Informational and analytical methods were used. In this study, the authors performed information and patent search concerning the natural seed regeneration of stands with pedunculate oak in the composition. The search was carried out both in Ukraine and in some European countries (Belgium, Germany, Poland, Hungary, France, Czech Republic, Sweden, etc.). The experience of Ukrainian and foreign scientists on the issue of regeneration of oak forests was generalized on the basis of analysis of 57 literature sources.

\section{Results and Discussion}

The best conditions for a good natural regeneration are created in the case of shelterwood or group selection felling. In Ukraine, the experiments on the study of these felling methods were carried out at the end of the $19^{\text {th }}$ century. By that time, only clearcutting was used, and natural regeneration of oak forests from seed was considered impossible.

Kornakovskiy (1904) was one of the first to substantiate the possibility of natural seed regeneration of oak stands after the clearcutting due to the young seedlings of pedunculate oak and common ash (Fraxinus excelsior L.), which are always available under the canopy of mature and overma- 
ture forest stands. After clearcutting and appropriate forestry activities (clearance of weeds, undergrowth and accompanying species), it is possible to grow young plants from seeds with the predominance of oak and ash in the composition.

Further studies by Zhukov (1949) confirmed the conclusion of Kornakovsky. He believed that in Ukrainian forests the natural regeneration of oak stands could be expected in the Western and Central Polissya zones and in the Left-bank Forest-Steppe zone in fresh and moist fertile oak forest types, in the case of shelterwood and group selection felling. Only careful tending is needed for the understory of young regeneration in the first years after the felling. In other regions of Ukraine, for example, Ravine Steppe, natural regeneration cannot be considered as a basis for forest management. However, the full advantage of the oak seed reproduction, if available, should be taken.

Investigating the peculiarities of natural (seed) regeneration in hornbeam (Carpinus betulus L.) forests in the Podillya zone, Ukraine, Shevchenko (1970) had determined the stand stocking influence on the composition of the advance growth under the canopy of the stands. He had examined the impact of existing felling systems on reforestation and had proposed a range of forestry activities for the renewal of oak stands in primary forest types. On the basis of these studies, the causes of mortality for the advance reproduction of the main species after clearcutting were revealed. Shevchenko attributed the mortality to the combined effect of the following factors: the light conditions have changed dramatically; the root system has not adapted to the conditions with an increased moisture evaporation from the upper soil layers; the more intense transpiration of leaves due to the wind and higher temperature that were not available under the canopy of the parent stand.

Studying the tree species regeneration under the canopy of close stands,
Atrokhyn and Kuznetsov (1989) discovered factors that contributed to or inhibited the emergence and development of advance seedlings. The researchers considered favorable conditions as the presence of abundant seeds, the sufficient amount of sunlight, the constant humidity of the soil surface, litter and forest live cover, no sudden temperature fluctuations, and poor turf formation. Unfavorable conditions included insufficient light availability, root competition (particularly from parent trees), dense forest litter, the presence of raw humus, and choking seedlings with leaf litter. In addition to ecological and biotic factors, anthropogenic ones play a significant role in the rise and development of advance growth of tree species. Among them, the most influential are various types of felling, grazing, haymaking, recreation activity, and fires.

Environmental optima for natural regeneration of pedunculate oak, common ash and Norway maple (Acer platanoides L.) were defined in the studies of combined influence of environmental factors, such as light under the canopy, depth of the humus layer, thermal and ombro-climate, humidity, acidity and salinity of soils, the nitrogen and carbonates content, on the morphology, viability and number of small-sized (up to $0.5 \mathrm{~m}$ ) seedlings of these species in forests of northeastern Ukraine (Sklyar, 2002; Sklyar \& Dehtyaryov, 2013). The light conditions and soil moisture were pointed out as the most important factors determining the state of oak reproduction. For ash, such determinants were the light amount, soil moisture, and thermal and ombro-climate. For maple, light, soil moisture, and thermal climate were essential.

According to Sorogovets (1958), the optimum light amount for the development of oak undergrowth was $31-48 \%$ of full sunlight; with less light, the advance growth was suppressed. Wiesner (1879) has shown that the normal growth and development of advance reproduction of tree species occurs at the illumination of at least 
2,100 lux (or $15-25 \%$ of full sunlight).

The results of studies by Annighöfer et al. (2015) in oak forests in South Germany suggested that the success of natural regeneration depended on the proportion of oaks in the stand composition and their age, the acorn yield, the sufficient amount of heat, moisture, light, and soil pH. Oak seedlings emerged also in unfavorable light conditions but as they developed, their need for light increased. After reaching the height of more than $1.0 \mathrm{~m}$, the light was the main factor affecting their survival. According to the data (Annighöfer et al., 2015), oak seedlings should receive at least $20 \%$ of light for successful growth while no more than $1-3 \%$ of the full sunlight passes through the canopy. Similar results were obtained by Ligot et al. (2013). According to Sevillano et al. (2016), at least $28 \%$ of the full sunlight is required for the survival and successful growth of advance oak reproduction.

Vizoso-Arribe et al. (2014), studying the relationship between the percentage of light reaching the undergrowth layer in the oak forest and the seedling density, noted that in sites with better lighting, a higher density of seedlings and saplings of tree species, including pedunculate oak, was discovered as a result of creating more favorable conditions for the germination of acorns.

During the survey of 3,505 hectares of floodplain oak forests in the southern part of the Czech Republic, Dobrovolný (2014) found only 8 hectares of the area with sufficient natural reproduction of pedunculate oak of 15-100 thousand stems ha ${ }^{-1}$ after felling. The study of natural oak reproduction under the stand canopy in different lighting conditions has shown that the largest number of the reproduction (more than 10 thousand stems ha-1) was found near the forest margin at a distance of $18 \mathrm{~m}$ from the edge at the illumination of above $24 \%$. Under the canopy of the stands, where the illumination was less than $24 \%$, common ash and field maple (Acer campestre L.) pre- vailed in the composition of the advance reproduction. In general, in the studied region, the use of existing natural seed reproduction in floodplain oak forests can serve as one of the variants of natural regeneration of valuable oak forests if a certain range of activities facilitating this process are implemented.

Osipov's investigation (Osipov et al., 1989) showed that the transformation of young oak seedlings into saplings was inhibited by the lack of light and their suppression by the undergrowth of fast-growing tree species: common ash, hornbeam, small-leafed lime (Tilia cordata Mill.), Norway maple and smooth-leafed elm (Ulmus carpinifolia G.).

By studying the development of natural seed regeneration in ChuhuyevoBabchansky forests of the Kharkiv region, Ukraine, Pyatnitskiy (1933) found that for the light conditions of $40 \%$ of full sunlight, the growth of 3-year-old oak trees was the same as under the full sunlight. The light-demand of oak is not constant and varies with age, and also depends on the geographical environment (Annighöfer et al., 2015). Old-aged stands are usually more thinned which allows covering their needs for light and nutrition elements in the best way. The shade tolerance of oak increases from north to south and as soil conditions improve. Light conditions affect the humidity and the temperature of the air and soil of the region and improve or worsen the herbaceous cover development. The vertical structure of a parent stand, the presence of undergrowth and advance growth, the thickness of the forest litter, and the moisture of the upper soil layer are also essential for young seedlings.

Kharchenko and Kharchenko (2012) studied the partial thinning of the first layer with the simultaneous cutting of the second layer and undergrowth with adjusting the relative density of stocking for the stand up to 0.6. The data indicated more than a three-fold increase in the light amount under the stand canopy. Re- 
ducing the relative density of stocking to 0.4 increased the temperature of the air under the canopy of the stand and promoted early germination of acorns. The young seedlings were then damaged by spring frosts; ground vegetation overgrew, suppressing the oak growth. In the southern Forest-Steppe zone in Ukraine (dry and fresh fertile sites), the reduction of the relative density of stocking up to 0.4 did not show positive results and even negatively affected the oak regeneration due to the intense drying of the surface soil layer. In the Shipov Forest, the Voronezh region, Russia, by the end of the first decade of July, the number of oak seedlings increased everywhere, and then they began to die in the thinned areas. The more intensely the stand was thinned, the more active the process was, due to moisture deficiency. In the fresh maple-lime oak forest sites in the north-east of the Left-bank Forest-Steppe zone of Ukraine, the Sumy region, the best results were noted after cutting down the shrub layer and lower tree layer and thinning of the canopy to the relative density of stocking of 0.5 (Chigrinets \& Ignatenko, 2015). In the dry maple-lime fertile oak site type of the Central Forest-Steppe zone of Ukraine, the relative stocking density of 0.6-0.7 was the optimum for the emergence of oak seedlings (Ryzhkov, 2001). In the conditions prevailing in the Left-bank Forest-Steppe zone, the greatest number of advanced oak seedlings was detected (Rumyantsev, 2015) in 80-121-year-old forest stands with a proportion of at least $80 \%$ of oak in the canopy layer and with the relative density of stocking below 0.7 (Table 1).

Table 1. Quantity of advance reproduction under the canopy of parent stands of different ages, compositions and relative densities of stocking in dry maple-lime fertile oak site type in Left Bank Forest-Steppe zone, Ukraine

\begin{tabular}{|c|c|c|c|c|c|c|}
\hline \multirow[t]{3}{*}{ Stand composition } & \multirow[t]{3}{*}{$\begin{array}{c}\text { Age } \\
\text { (years) }\end{array}$} & \multirow{3}{*}{$\begin{array}{l}\text { Relative } \\
\text { density } \\
\text { of } \\
\text { stocking }\end{array}$} & \multicolumn{3}{|c|}{ 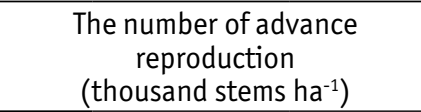 } & \multirow[t]{3}{*}{$\begin{array}{l}\text { Advance reproduction } \\
\text { composition }\end{array}$} \\
\hline & & & \multirow[t]{2}{*}{ Total } & \multicolumn{2}{|c|}{ Including } & \\
\hline & & & & $\begin{array}{l}\text { pedunculate } \\
\text { oak }\end{array}$ & $\begin{array}{l}\text { common } \\
\text { ash }\end{array}$ & \\
\hline $\begin{array}{l}\text { 0ak } 60 \%-\text { Ash } \\
20 \%-N-\text { Maple } 20 \%\end{array}$ & 50 & 0.74 & 6.4 & 0.5 & 1.6 & $\begin{array}{l}\text { N-Maple } 70 \% \text {-Ash 20\%-0ak } \\
10 \%\end{array}$ \\
\hline $\begin{array}{l}\text { Oak } 70 \% \text {-Ash } \\
20 \%-N-\text { Maple } 10 \%\end{array}$ & 61 & 0.76 & 6.8 & 0.6 & 1.4 & $\begin{array}{l}\text { N-Maple } 60 \% \text {-Ash } 10 \% \text {-0ak } \\
10 \% \text {-Elm } 10 \%\end{array}$ \\
\hline $\begin{array}{l}\text { Oak } 80 \%-N-M a p l e \\
10 \% \text { - Lime } 10 \%\end{array}$ & 70 & 0.80 & 5.9 & 0.5 & - & $\begin{array}{l}\text { N-Maple } 70 \% \text {-F-Maple } 10 \%- \\
\text { Lime 10\%-0ak 10\% }\end{array}$ \\
\hline $\begin{array}{l}\text { Oak 60\%-Ash 30\%- } \\
\text { Lime 10\% }\end{array}$ & 81 & 0.82 & 12.3 & 0.6 & 1.9 & $\begin{array}{l}\text { N-Maple 50\%-F-Maple 30\%- } \\
\text { Ash 20\% }\end{array}$ \\
\hline $\begin{array}{l}\text { Oak 80\%-F-Maple } \\
10 \% \text {-Ash } 10 \%\end{array}$ & 83 & 0.69 & 20.5 & 10.4 & 0.9 & $\begin{array}{l}\text { Oak 50\%-F-Maple 30\%-Elm } \\
\text { 10\%-Ash 10\% }\end{array}$ \\
\hline 0ak 90\%-Ash 10\% & 100 & 0.50 & 11.5 & 0.8 & 6.4 & $\begin{array}{l}\text { Ash } 60 \%-N-\text { Maple } \\
20 \%-\text { F-Maple } 10 \%-0 \text { ak } 10 \%\end{array}$ \\
\hline Oak 100\% & 118 & 0.52 & 6.8 & 0.3 & 1.0 & $\begin{array}{l}\text { N-Maple } 40 \% \text {-F-Maple } 30 \%- \\
\text { Ash 10\%-Elm 10\%-Aspen } \\
10 \%\end{array}$ \\
\hline $\begin{array}{l}\text { Oak } 80 \% \text {-Lime } 10 \%- \\
\text { N-Maple } 10 \%\end{array}$ & 121 & 0.61 & 12.8 & 5.6 & - & $\begin{array}{l}\text { Oak 40\%-F-Maple 30\%- } \\
\text { N-Maple 30\% }\end{array}$ \\
\hline
\end{tabular}

Note: Oak = pedunculate oak (Quercus robur L.), Ash = common ash (Fraxinus excelsior L.), N-Maple = Norway maple $($ Acer platanoides L.), F-Maple = field maple (Acer campestre L.), Lime - small-leafed lime (Tilia cordata Mill.), Elm = wych elm (Ulmus glabra Huds.), Aspen = aspen (Populus tremula L.). 
In the Right-bank Forest-Steppe zone of Ukraine, the largest number of oak reproduction (2.5-34.0 thousand stems ha $\left.^{-1}\right)$ was found under the canopy of medium-stocked (0.6-0.7) stands, and the smallest one was in fully stocked (0.8-1.0) stands (Levchenko, 2014). Increasing the relative stocking density of a stand up to 0.8 and above contributed to the light amount reduction under the canopy of oak stands, thereby affecting the growth and development of the oak reproduction (0.3-3.0 thousand stems ha-1). Reducing the relative stocking density of the oak stand up to $0.4-0.5$ led to the sedge-grass vegetation overgrowth as well as undergrowth spreading, which prevented the sprouting of acorns and retarded the normal growth and development of advanced oak seedlings (4.3-14.3 thousand stems ha-1).

According to Melekhov (1975), an advance oak regeneration could occur under the canopy of oak stands with a different relative density of stocking, but the seedlings remained healthy for a short period. The optimum environment for the emergence of oak seedlings and their successful growth was created when the relative density of stocking was 0.6-0.7. A sharp decrease in the stocking density up to $0.3-0.4$ caused damage to the advanced oak seedlings due to the drying of the soil, the frost effects, and other adverse factors. Young oak seedlings were particularly susceptible to low air and soil temperatures. The degree of frost resistance of 1-3-year-old oak trees depended on their preparation for the winter. The aboveground part of the less-developed seedlings was killed by frost at $-13^{\circ} \mathrm{C}$, and of healthy developed seedlings, at $-35^{\circ} \mathrm{C}$. Frost resistance of young oak trees decreased in the spring, during dormancy release. Young spring shoots died at $-4^{\circ} \mathrm{C}$ within $6-8$ hours.

The soil moisture is a significant factor in the emergence and development of the advance reproduction; it depends on the structure of a stand and canopy density (Kharchenko \& Kharchenko, 2012). Under the canopy of closed stands, the balance between precipitation and evaporation is stable. In understocked stands, the amount of precipitation getting through the canopy increases but, on the other hand, there are conditions for increasing evaporation from the soil surface and water consumption by undergrowth and ground vegetation. In Steppe and Forest-Steppe conditions in Ukraine there is some moisture imbalance, so a deterioration in growth conditions was found for young oak seedlings under the canopy of understocked stands. In the cut-over areas, the soil moisture level was almost twice as low as in a closed stand. In understocked stands, evaporation was 1.7 times higher than in fully stocked ones. Consequently, the decrease in soil moisture negatively affected the oak seedling emergence in understocked stands. The most favorable conditions for advance oak regeneration were found to be in Polissya and Forest-Steppe zones with a sufficient amount of heat and moisture.

During the years of abundant fruiting, the maximum number of young seedlings of pedunculate oak was registered under the canopy of mature stands with a relative density of stocking of $0.5-0.7$ and in the stands where a set of activities on natural regeneration assistance have been implemented (Hensiruk, 2002). For example, in 1983, about 200 thousand stems ha ${ }^{-1}$ of young oak seedlings were accounted in the moist fertile hornbeam-oak forest conditions in the Lviv region, Ukraine, under the canopy of an oak stand with 90 pedunculate oaks and 10 hornbeams in the composition and the relative density of stocking of 0.7. A significant number of oak seedlings and samplings was also recorded in medium-stocked stands in the Forest-Steppe zone of Ukraine (Hensiruk, 2002).

The results of the research performed by Levchenko (2005) in fresh oak forests in the Kyiv region of Ukraine indicated that the optimum amount of sunlight for the growth and development of oak reproduction under the canopy of the parent 
stand can be provided by thinning the undergrowth. The undergrowth must be cut down completely in fully stocked stands, by $60 \%$ in medium-stocked stands and by $40-50 \%$ in understocked ones. The number of advanced seedlings of the main and associated species reached 12.4 thousand per hectare in maturing oak stands and 18.0 thousand per hectare in mature and overmature ones.

Studying the competition of young oak trees with more rapidly growing species and shrubs in the south of Sweden in the Dalby Söderskog National Park, Finnström (2016) has found that the more competing plants surrounded the oak seedlings within a radius of $2 \mathrm{~m}$, the smaller were the diameter at breast height $(1.3 \mathrm{~m})$, length and diameter of the crown and the total height of the young oaks. Common beech (Fagus sylvatica L.) and common hazel (Corylus avellana L.) most negatively impacted on the development of the advanced pedunculate oak seedlings. A moderate impact was marked for smooth-leafed elm and oak; common ash was the least negatively impacting species. A small number of plants around oak seedlings facilitated their growth, improving the microclimate and protecting from ungulate browsing. The height of such oak trees was larger, compared to those that grew in the open area. The positive effect of shrubs on the protection of the small seedlings of pedunculate oak and sessile oak (Quercus petraea (Matt.) Liebl.) against ungulate browsers in temperate broadleaved forests in southern Sweden was revealed by Jensen and Löf (2017). However, shrubs can also negatively influence the growth and development of natural oak reproduction. As an example, the study of Muhamed et al. (2015) in the coastal forestlands of southwest France showed a positive effect of Fagaceae shrubs on the growth of the young oak generation as well as the negative influence of Ericaceae shrubs and no significant influence for the Fabaceae group and spiny shrubs.

A forest live cover affects the preserva- tion and survival of advance reproduction of tree species both under the canopy of oak stands and on cut-over lands. The highest number of seedlings was recorded on the cut-over area one year after the cutting, up to 6.5 thousand stems ha-1 (Levchenko, 2014). This was due to the lack of forest litter and less competition for light, nutrients, and moisture from sedge-grass plants (the abundance was 5-20\%). The increase in the abundance of the plants up to $50 \%$ led to a significant reduction in the number of natural reproduction, up to $0.2-1.8$ thousand stems $\mathrm{ha}^{-1}$, on cut-over areas 2-5 years after the felling. Under the canopy of oak stands, harmful temperature fluctuations and competition from the herbaceous cover were less than those on cut-over areas 2-5 years after the felling; therefore the number of seedlings was greater, 5.0 thousand stems ha-1.

Sendonin (2015) investigated the changes in natural seed regeneration of oaks in fresh fertile oak forests in the southern part of the Right-bank Forest-Steppe zone, Ukraine. He has established the dependence of regeneration success on a number of factors, in particular, on the acorn harvest abundance, the thickness of forest litter, and the light amount. The poor regeneration of oak was noted in the Forest-Steppe zone in the conditions of the fresh oak-hornbeam fertile site type, both under the canopy of a forest stand and on cut-over areas 1-3 years after the felling. In these conditions, 3-year-old natural seed reproduction of the associated species was at least 12 thousand stems ha ${ }^{-1}$. It is therefore appropriate to use the combined regeneration in forestry production.

According to Romashov (1973), the ground cover with predominantly goutweed (Aegopodium podagraria L.) provides the best conditions for the natural regeneration of oak. The cover protects young oak seedlings from sunscald and frosts and does not inhibit them with own root systems. The goutweed type of cut-over areas is mainly formed in conditions of fresh and 
moist fertile oak sites. In such areas after clearcutting in a mast year, advance oak seedlings grew for 4-5 years in a quantity of 10-60 thousand stems ha-1, in the amount sufficient for the natural regeneration of oak forests, and then died. In sedge-goutweed types of cut-over areas, the conditions for the growth and development of oak advanced reproduction were worse. The worst conditions were observed in sedge types of the cut-over areas, where the number of seedlings was only $0.4-0.6$ thousand stems $\mathrm{ha}^{-1}$. The same opinion was expressed by Berezhnoy (1971) after the investigation in Trostyanetske Forestry Enterprise, Sumy region, Ukraine.
In the Left-bank Forest-Steppe zone of Ukraine, a favourable environment for the natural regeneration of valuable species is created under the canopy of mixed natural oak stands in fertile and fairly fertile oak forest site types after a seed year. The most active natural regeneration occurred in older forests, specifically in mature and overmature stands (Figure 2). Forestry activities aimed at the regeneration of such stands in a natural way should be introduced, necessarily taking into account the periodicity of oak fruiting (Didenko, 2008; Tkach et al., 2014b; Tkach et al., 2015; Rumyantsev, 2015; Rumiantsev, 2016).

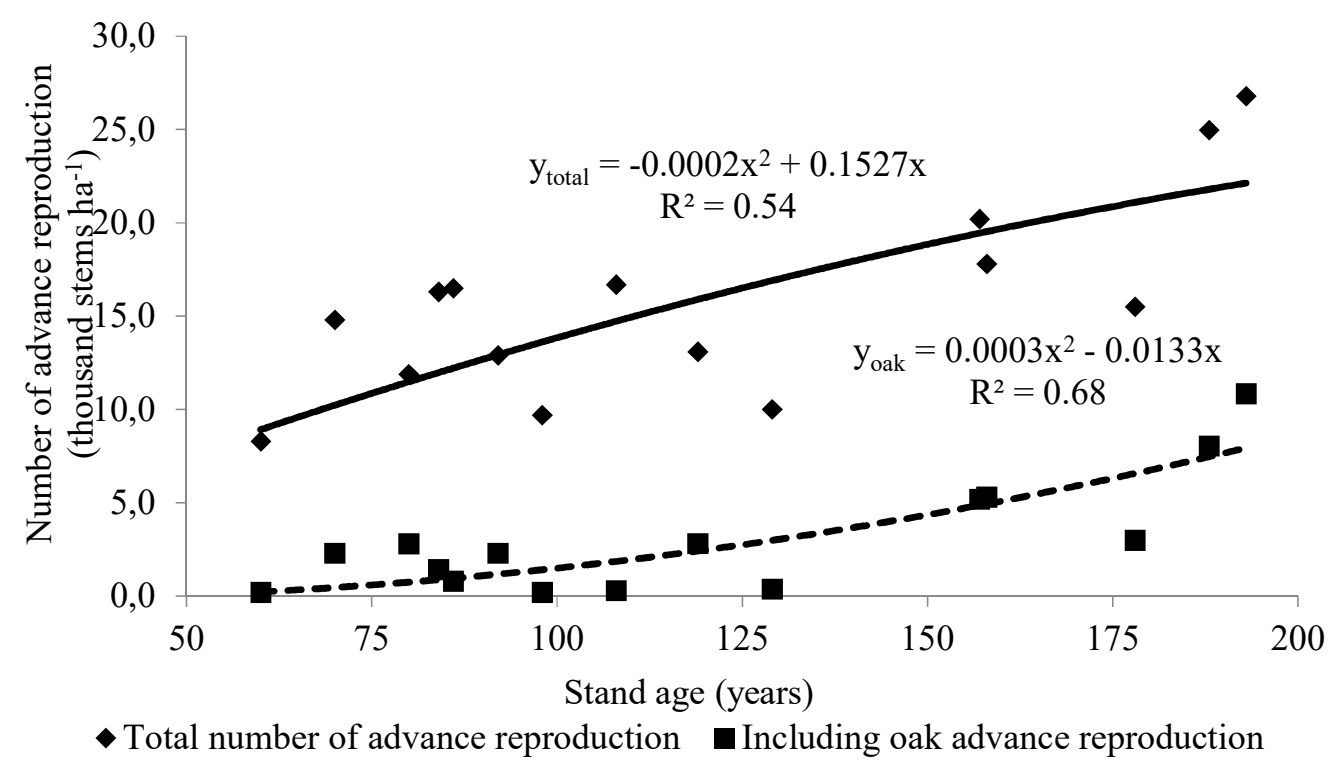

Figure 2. Dependence of advance reproduction quantity on the age of stands.

The number of advanced oak seedlings was in the range of $3.8-17.3$ thousand stems ha-1 in all types of oak forests in the Polissya zone, 24.2-61.5 thousand stems $\mathrm{ha}^{-1}$ in the western Podillya zone, and 0.7-186 thousand stems ha ${ }^{-1}$ in the Forest-Steppe zone (Chernyavskiy, 1989). In the Polissya zone, the best oak seed reproduction was observed in the moist fertile hornbeam-oak forest sites and in fresh fair- ly fertile hornbeam-pine oak forest sites. In the Forest-Steppe zone, the best seed reproduction occurred in fresh and moist fairly fertile hornbeam-oak forest sites and in fresh ash-lime oak forests. A large number of advanced oak seedlings, up to 100 thousand stems ha $^{-1}$, were also recorded in the second and third year following a mast year both under a stand canopy and on cut-over areas. In reforestation process- 
es, the competitor of oak was hornbeam; only in dry hornbeam-oak forests in the southern regions of the Forest-Steppe zone of Ukraine, the regeneration of hornbeam was unsatisfactory.

However, even with abundant fruiting and favorable conditions for seed germination and seedling emergence, it can not be said that the regeneration of a species is successful. A large number of self-seeded oaks is not yet a guarantee of their transformation into a young generation that will substitute an existing stand. This was the view of Coates (2002) who suggested that the most important reforestation factor was not the successful fruiting of a tree species, but the further development and survival of the small advanced seedlings.

After abundant harvest of oak acorns in the Right-bank Forest-Steppe zone in Ukraine, large numbers of oak seedlings, up to 48 thousand stems ha $^{-1}$, emerged under a stand canopy in fresh fertile hornbeam-oak forest sites. However, only half of them survived by autumn of the same year due to unfavorable conditions, including high canopy density, oak powdery mildew affection and others (Fedets et al., 1987). In the Right-bank Forest-Steppe and Polissya zones, the natural regeneration of oak can be ensured on $5-10 \%$ of cut-over areas in fertile and fairly fertile oak forest site types while in the Left-bank Forest-Steppe zone, only on $2-5 \%$ of the area, and it is subject to availability of the abundant harvest of acorns.

Vedmid et al. (2008) have investigated the advance regeneration in native and secondary stands in the fresh fertile oak forest sites in the Left-bank zone of Ukraine during 2006-2008. The authors recorded the natural seed reproduction of oak and ash at the age of 4-8 years in the range of 1.0-1.4 thousand stems ha ${ }^{-1}$ under the canopy of secondary aspen and birch stands and in the range of 1.5-2.9 thousand stems $\mathrm{ha}^{-1}$ under the canopy of native stands. The density of advanced seedlings under the canopy of the secondary stands was small- er compared with that of under crowns of native stands. The advanced natural regeneration in the native oak stands growing in fresh fertile oak sites is intended to be replaced with forest plant communities with other species being predominant, namely Norway maple, field maple, smooth-leafed elm, and small-leafed lime.

The study of the patterns of forest regeneration under the canopy of oak-hornbeam stands and on cut-over areas in fresh fertile oak sites in Cherkasy region, Ukraine, led Ischuk (2017) to conclude that the stands of the fertile oak forest type had naturally regenerated with little involvement of young oaks. As a result, the native oak stands were replaced by low-value hornbeam saplings. Under the canopy, the most successful was the natural regeneration of hornbeam: the number of hornbeam seedlings was double that of the oak. The determining environmental factor that affected the preservation, growth and development of oak seedlings was low light. Under the canopy of fully stocked oak and hornbeam stands the light amount reached only $0.5-3.0 \%$ of the full sunlight, resulting in the gradual loss of oak seedlings in the second or third year. The natural reproduction of oak on regenerated cut-over areas was growing well but its proportion was insignificant and amounted to only $1 \%$.

Lositskiy (1963) also confirmed the predominance of hornbeam self-seeding with a small fraction of oak in the oak forests of the fresh cut-over areas of Podillya, Ukraine. Common ash (14\%), Norway maple $(9 \%)$ and small-leafed lime $(23 \%)$ seedlings were found, as well, in one-yearold cut-over areas as a part of the advance growth. Megalinskiy (1965) also argued that cut-over areas in the oak stands of the Right-bank Forest-Steppe zone of Ukraine were overgrown with the advance growth of ash, maple, hornbeam, lime, and other species. There were 13 to 15 thousand ash seedlings per hectare and 0.1 to 7-8 thousand stems ha ${ }^{-1}$ of oaks.

From the study on cut-over areas 1-6 
years after cutting in fresh fertile hornbeam-oak forests of the southern part of the Right-bank Forest-Steppe of Ukraine, Ostapchuk et al. (2014) indicated over 6 thousand stems ha $^{-1}$ of natural reproduction for all species and up to 2.9 thousand stems ha-1 for the seed reproduction of oak. On the one-year-old fresh cut-over site, hornbeam was prevailing in advance reproduction (5.8-8.5 thousand stems ha-1) and in the 2-year-old cut-over areas, common ash dominated (15.8-19.0 thousand stems ha-1). Norway maple prevailed on the 3-year-old cutting site (17.3-23.5 thousand stems $\mathrm{ha}^{-1}$ ) and hornbeam on the 4-year-old cutting site (7.5-11.0 thousand stems ha-1); common ash was dominating in the 5-year-old cut-over area (16.5-22.8 thousand stems ha-1) and Norway maple in the 6-year-old cutting areas (8.5-12.0 thousand stems ha ${ }^{-1}$ ). Livability of healthy natural reproduction of pedunculate oak as a part of an advance reproduction in the conditions of fresh fertile oak forests in the Right-bank Forest-Steppe could be expected, only if regular and careful forest tending for this species is carried out.

Bondar (2004), after studying regeneration of various species on 59 cut-over sites in the oak stands of Podillya, Ukraine, reported that the reproduction in the cutover areas was above 3 thousand stems $\mathrm{ha}^{-1}$, taking into account all species according to the classification (Pasternak, 1990). From 3 to 6 thousand stems ha ${ }^{-1}$ of advance reproduction of pedunculate oak and common ash were detected in only 10 cut-over plots, while in other 49 plots the reproduction number was 1.5-2.9 thousand stems ha-1. Among the other species, the most abundant natural seed reproduction was detected for hornbeam, slightly less for Norway maple, and the least for lime. According to the study (Bondar \& Hordyenko, 2006), hornbeam had the best conditions for its development in the fresh fertile oak forest site type. For example, on the 3-year-old cut-over site in the Vinnitsa region, Ukraine, in fresh hornbeam-oak forest, the number of hornbeam advance reproduction was 28.0 thousand stems $\mathrm{ha}^{-1}$. The advance reproduction of ash, hornbeam, lime, and Norway maple was higher than that of pedunculate oak; this was a threat to the oak survival. In such areas, timely tending is required in order to preserve the oak. The greatest number of advance reproduction of all species was detected in oak stands with a relative stocking density of $0.6-0.7$ in amounts of 32.0-33.0 thousand stems ha ${ }^{-1}$.

An investigation of the areas after clearcutting of oak stands in Ukrainian Podillya (Matusyak, 2016) showed a significant potential for using the natural reproduction to ensure the regeneration of forest stands. The success of the natural regeneration depended on the harvest cutting time, available fruiting in the year prior to the cutting, the proportion of oak in the stand composition and how evenly oak trees were spaced over the area. Under optimum conditions, it is possible to establish natural regeneration of pedunculate oak at 3.0-5.0 thousand stems ha $^{-1}$ in $1-2$ years after clearcutting.

V. Tkach et al. (2014a) carried out regeneration felling with the use of elements of even gradual felling, group successive felling, and felling with complete removal of trees in strips of $25 \mathrm{~m}$ in width in the conditions of the Left-bank Forest-Steppe zone, Ukraine. The authors concluded that a resilient natural reproduction of valuable species emerged on the experimental plots where the regeneration felling began in the year of good oak fruiting and preliminary activities were conducted in the stands to promote natural regeneration (loosening of litter, removal of undergrowth and weakened trees, leaving the seed trees). The best natural seed-origin reproduction of the main species, oak and ash, was found on sites where the elements of clear narrow-coupe felling and even gradual felling were used and over 4 thousand stems ha-1 of natural reproduction at the age of 9 were indicated (Figure 3). In 
such plots, the numbers of good advance reproduction of oak and ash were the largest. In the variants of the experiment where elements of group successive felling were used, the number of natural reproduction of economically valuable species was also sufficient but the proportion of oak in it was much smaller (Table 2).

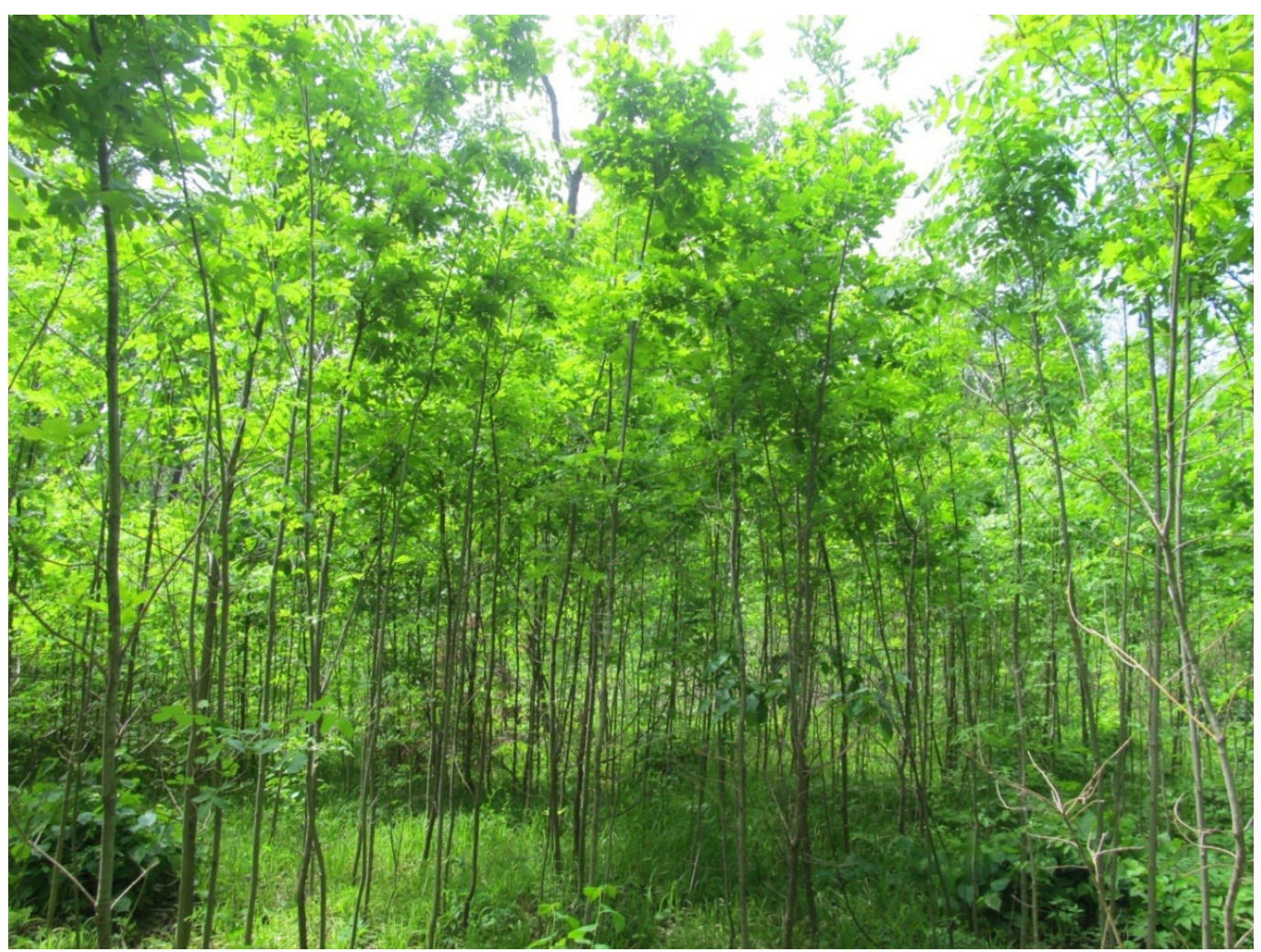

Figure 3. Natural reproduction at the age of 9 after regeneration felling with complete removal of trees in 25-meter-wide strips. 
Table 2. Characteristic of natural reproduction in different variants of regeneration felling (as of 2018)

\begin{tabular}{|c|c|c|c|c|c|c|}
\hline \multirow[t]{2}{*}{ Species } & \multicolumn{3}{|c|}{$\begin{array}{l}\text { The number of advance } \\
\text { reproduction by age groups } \\
\text { (thousand stems ha-1) }\end{array}$} & \multirow[t]{2}{*}{$\begin{array}{l}\text { Proportion of the } \\
\text { species in the } \\
\text { composition (\%) }\end{array}$} & \multirow[t]{2}{*}{$\begin{array}{c}\text { Abundance } \\
(\%)\end{array}$} & \multirow[t]{2}{*}{$\begin{array}{l}\text { Regeneration } \\
\text { success }\end{array}$} \\
\hline & $\begin{array}{c}4-8 \\
\text { years }\end{array}$ & $\begin{array}{l}9-15 \\
\text { years }\end{array}$ & Total & & & \\
\hline \multicolumn{7}{|c|}{ Even gradual felling } \\
\hline Pedunculate oak & 5.64 & 6.11 & 11.75 & 54.3 & 100 & \multirow{6}{*}{ Good } \\
\hline Common ash & 2.76 & 5.74 & 8.50 & 39.3 & 90 & \\
\hline Norway maple & - & 0.50 & 0.50 & 2.3 & 40 & \\
\hline Field maple & - & 0.13 & 0.13 & 0.6 & 10 & \\
\hline Small-leafed lime & - & 0.75 & 0.75 & 3.5 & 50 & \\
\hline Total & 8.40 & 13.23 & 21.63 & 100 & - & \\
\hline \multicolumn{7}{|c|}{ Strip gradual felling with complete removal of trees in $25 \mathrm{~m}$ width strips } \\
\hline Pedunculate oak & 4.32 & 8.01 & 12.33 & 59.6 & 100 & \multirow{5}{*}{ Good } \\
\hline Common ash & 1.23 & 6.44 & 7.67 & 37.0 & 80 & \\
\hline Norway maple & 0.10 & 0.35 & 0.45 & 2.2 & 30 & \\
\hline Small-leafed lime & - & 0.25 & 0.25 & 1.2 & 20 & \\
\hline Total & 5.65 & 15.05 & 20.70 & 100 & - & \\
\hline \multicolumn{7}{|c|}{ Group successive felling } \\
\hline Pedunculate oak & 0.20 & 1.00 & 1.20 & 20.7 & 50 & \multirow{5}{*}{ Sufficient } \\
\hline Common ash & 0.60 & 3.20 & 3.80 & 65.5 & 70 & \\
\hline Norway maple & - & 0.40 & 0.40 & 6.9 & 30 & \\
\hline Small-leafed lime & 0.10 & 0.30 & 0.40 & 6.9 & 30 & \\
\hline Total & 0.90 & 4.90 & 5.80 & 100 & - & \\
\hline
\end{tabular}

\section{Conclusions}

The review of the literature on natural seed-origin regeneration in oak forests both in Ukraine and other European countries demonstrates controversial scientific conclusions since the studies were conducted in different years, in different forest site conditions as well as by use of different methods. The success of the natural seed regeneration of oak is determined by the appropriate selection of felling methods, by activities to promote natural regeneration and by a set of factors that become limiting in the specific conditions.
The most favorable conditions for the oak natural seed regeneration in Ukraine are the conditions of the Polissya and Forest-Steppe zones, namely fresh and moist fertile oak forest types, with a sufficient amount of heat and moisture. The main factors that contributed to the emergence and growth of oak seedlings were the following: the high seed yield, sufficient light amount (at least $20 \%$ of full sunlight), the constant moisture of the soil surface, litter and forest live cover, no sudden temperature fluctuations, and poor turf formation. The determining environmental factor, according to many studies, was the light 
conditions. These affected the humidity and temperature of the air and soil of the region; also, they improved or worsened the development of the forest live cover. The adverse factors for the regeneration were the following: the root competition from the parent trees, the dense forest litter, the presence of raw humus, the dense undergrowth, and the high relative stocking density of the parent canopy ( 0.8 and more). The optimum environment for the emergence and development of oak seedlings as well as for their growth was formed in the stands with the relative density of stocking of $0.6-0.7$. In addition to abiotic and biotic factors, anthropogenic ones also played an important role in the emergence and development of the advance growth of tree species. Among them, the most influential were various types of felling, grazing, haymaking, recreation activities, and fires.

In order to increase the maximum number of self-seeding of oak and preserve it during felling, the following activities are required to promote natural regeneration:

-5-7 years prior to the final or regeneration felling, thinning is necessary to reduce the relative density of stocking to $0.6-0.7$; this would improve acorn production;

- it is necessary to cut down the undergrowth in the stands of approaching maturity and mature stands in a year of abundant oak fruiting (or a year later). The undergrowth should be cut completely in fully stocked stands (the relative density of stocking is $0.8-1.0$ ), by $60 \%$ in mediumstocked stands (with the relative density of stocking of $0.5-0.7$ ) and by $40-50 \%$ in understocked stands (0.4 and below), which will ensure the massive emergence of oak seedlings as well as their normal growth and development;

- in the autumn of a seed year in the period of mass fall of acorns (October), the soil should be loosened. The soil tilling should be conducted to a depth of 7-10 cm in strips or areas, accounting for $20-35 \%$ of the total area of the plot;
- cutting should be carried out after the acorn fall and before the emergence of oak seedlings in the autumn-winter period of a seed year. In the case of a sufficient number of viable seedlings, the cutting can be executed in the winter period if a stable snow cover forms for better preservation of self-seeding and advance growth;

- in the case of an insufficient number of natural oak reproduction or a necessity for cutting in non-seed years, acorns are partially overseeded under the forest canopy in the spring 1-2 years prior to the final or regeneration felling.

- the advance growth of oak should be assisted in the competitive activity against herbaceous vegetation in the first four years of life by mowing it or by herbicide application. The assistance after four years should be aimed at controlling the competitive effects of accompanying species.

In keeping with our recommendations, the proportion of areas of natural oak stands reproduced by seed may be increased by $10-15 \%$ of the total area of oak stands, which will significantly increase the disease resistance, lifetime and wood quality of the oak forests.

\section{References}

Annighöfer, P., Beckschäfer, P., Vor, T., Ammer, C. 2015. Regeneration Patterns of European Oak Species (Quercus petraea (Matt.) Liebl., Quercus robur L.) in Dependence of Environment and Neighborhood. - PLoS ONE, 10(8), art. no. e0134935. https://doi.org/10.1371/journal. pone. 0134935 .

Atrokhyn, V.H., Kuznetsov, H.V. 1989. Forestry. Moscow, Agropromizdat. 231 pp. (In Russian).

Berezhnoy, M.I. 1971. The change in grass cover influenced by progressive and clear-cutting in fresh maple-lime oak forests on the South of the Sumy region. - Ukrainian Botanical Journal, 28(3), 343-350. (In Russian).

Bobiec, A., Jaszcz, E., Wojtunik, K. 2011. Oak (Quercus robur L.) regeneration as a response to natural dynamics of stands in European hemiboreal zone. - European Journal of Forest Research, 130(5), 785-797.

Bondar, A.O. 2004. Regeneration of wood plants on cutting. - Scientific Bulletin of UNFU, 14.6, 154-165. (In Ukrainian). 
Bondar, A.O., Hordyenko, M.I. 2006. Forest stands formation in oak forests of Podillya. Kyiv, Urozhay. 334 pp. (In Russian).

Chernyavskiy, N.V. 1989. Features of regeneration of oak forests in the Forest-Steppe zone of Ukraine. - Forestry and Forest Melioration, 78, 3-7. (In Russian).

Chigrinets, V.P., Ignatenko, V.A. 2015. Features of pedunculate oak regeneration depending on forest stands thinning degree in the fresh maple-linden oak forests in the northeastern part of the Left-bank Forest-Steppe of Ukraine. - Bulletin of Sumy NAU. Series: Agronomy and biology, 9, 224-227. [WWW document]. - URL http://nbuv.gov.ua/UJRN/Vsna agro_2015_9_54. [Accessed 21 December 2018]. (In Ukrainian).

Coates, K.D. 2002. Tree recruitment in gaps of various size, clearcuts and undisturbed mixed forest of interior British Columbia, Canada. Forest Ecology and Management, 155(1-3), 387-398.

Didenko, M.M. 2008. Peculiarities of natural regeneration of oak forests in fresh maple-lime fertile oak site type. - The Bulletin of Kharkiv National Agrarian University. Series: Soil science, agricultural chemistry, agriculture, forestry, and soil ecology, 4, 112-114. (In Ukrainian).

Didenko, M.M., Vlasov, V. M. 2006. Diversity of oak forests in Mokhnachanske forestry in fresh maple-lime oak forest site type. - Proceedings of International Scientific Conference of students, graduate students and young scientists, Ukraine, Oct. 2006. Kharkiv, 106107. (In Ukrainian).

Dobrovolný, L. 2014. Potential of natural regeneration of Quercus robur L. in floodplain forests in the southern part of the Czech Republic. - Journal of Forest Science, 60(12), 534-539. http://dx.doi. org/10.17221/83/2014-JFS.

Dobrowolska, D. 2008. Effect of stand density on oak regeneration in flood plain forests in Lower Silesia, Poland. Forestry. - An International Journal of Forest Research, 81(4), 511-523. https://doi.org/10.1093/forestry/cpn025.

Fedets, Y.F., Kuchma, N.D., Tkachenko, B.V., Tshuk, A.A. 1987. Oak natural regeneration in Ukrainian Soviet Socialist Republic. Forestry and Forest Melioration, 75, 3-5. (In Russian).

Finnström, O. 2016. Regeneration dynamics of pedunculate oak in natural temperate forests: a case from southern Sweden. Swedish University of Agricultural Sciences. Master Thesis no. 251. Alnarp, Southern Swedish Forest Research Centre. 42 pp. [WWW document]. - URL https://stud.epsilon. slu.se/8899/1/finnstrom_o_160304.pdf. [Accessed 21 December 2018].

Götmark, F., Kiffer, C. 2014. Regeneration of oaks (Quercus robur/Q. petraea) and three other tree species during long-term succession after catastrophic disturbance (windthrow). - Plant
Ecology, 215(9), 1067-1080.

Hensiruk, S.A. 2002. Forests of Ukraine. Third edition. Lviv, USFU. 496 pp. (In Ukrainian).

Ikauniece, S., Brūmelis, G., Kondratovičs, T. 2012. Naturalness of Quercus robur stands in Latvia, estimated by structure, species, and processes. - Estonian Journal of Ecology, 61(1), 64-81. https:/ / doi.org/10.3176/eco.2012.1.07.

Ischuk, G.P. 2017. Natural regeneration of oak and hornbeam under the canopy and on cutting areas in the State Enterprise "KorsunShevchenko Forestry". - Scientific Bulletin of UNFU, 27(1), 15-18. [WWW document]. - URL http://nv.nltu.edu.ua/index.php/journal/ article/view/152. [Accessed 21 December 2018]. (In Ukrainian).

Jensen, A.-M., Löf, M. 2017. Effects of interspecific competition from surrounding vegetation on mortality, growth and stem development in young oaks (Quercus robur). - Forest Ecology and Management, 392, 176-183.

Kharchenko, N.A., Kharchenko, N.N. 2012. To a question of natural renewal of an oak (Quercus robur) under crones of a parent forest stand. Scientific Journal of KubSAU, 76(02), 357-369. (In Russian).

Kopiy, L.I., Fizyk, I.V., Baran, S., Lavnyy, V.V., Kopiy, S.L., Presner, R.B., Agij, V.O. 2017. Natural seed reproduction of oak plantations as an element close to the nature forestry. - Scientific Bulletin of UNFU, 27(9), 9-13. (In Ukrainian). https://doi. org/10.15421/40270901.

Kornakovskiy, G.A. 1904. About oak stand regeneration in Tellerman grove. Lesopromyshlennyy vestnik, 43, 43-48. (In Russian).

Laurent, L., Mårell, A., Balandier, P., Holveck, H., Saïd, S. 2017. Understory vegetation dynamics and tree regeneration as affected by deer herbivory in temperate hardwood forests. iForest, 10, 837-844. https://doi.org/10.3832/ ifor2186-010.

Levchenko, V.V. 2005. Effect of light amount on the quantity and quality of natural seed regeneration under a forest canopy in the fresh fertile oak forest site type in the Kyiv region. - Scientific Bulletin of National Agrarian University, 83, 192-202. (In Ukrainian).

Levchenko, V.V. 2014. Perspectives of use of natural regeneration in oak forests in the Forest-Steppe zone on Right bank of Dnieper. - Scientific Bulletin of NULES of Ukraine, 198(1), 58-62. (In Ukrainian).

Ligot, G., Balandier, P., Fayolle, A., Lejeune, P., Claessens, H. 2013. Height competition between Quercus petraea and Fagus sylvatica natural regeneration in mixed and uneven-aged stands. - Forest Ecology and Management, 304(15), 391-398. https://doi. org/10.1016/j.foreco.2013.05.050.

Lositskiy, K.B. 1963. Regeneration of oak forests. Moscow, Izdatelstvo selskokhozyaystvennoy literatury, 360 pp. (In Russian). 
Matusyak, M.V. 2016. The assessment of the effectiveness of using natural regeneration of pedunculate oak (Quercus robur L.) at reforestation in clear cutting areas in the conditions of fresh hornbeam oak forests in Podillya. - Scientific Bulletin of UNFU, 26(4), 110-116. (In Ukrainian). https://doi. org/10.15421/40260417.

Megalinskiy, P.M. 1965. Natural regeneration and increasing production of stands. - Davydov, V. (ed.). Ways to improve forest productivity. Kyiv, Urozhay, 40-45. (In Russian).

Melekhov, I.S. 1975. Biology, ecology and geography of forest regeneration. - Melekhov, I.S., Rodin, A.R. (eds.). Forest regeneration. Moscow, Kolos, 4-22. (In Russian).

Muhamed, H., Lingua, E., Maalouf, J.-P., Michalet, R. 2015. Shrub-oak seedling spatial associations change in response to the functional composition of neighbouring shrubs in coastal dune forest communities. - Annals of Forest Science, 72(2), 231-241. https://doi.org/10.1007/s13595-014-0419-8.

Ortmann-Ajkai, A., Csicsek, G., Lukács, M., Horváth, F. 2017. Regeneration patterns in a pedunculate oak (Quercus robur L.) Strict forest reserve in Southern Hungary. - Sumarski List, 141(1-2), 39-46.

Osipov, V.V., Selochnik, N.N., Ilyushenko, A.F. 1989. The state of oak forests in the foreststeppe zone. Moscow, Publishing House of Academy of Sciences of the USSR, 230 pp. (In Russian).

Ostapchuk, A.S.,. Kuzovich, V.S., Debrynyuk, Yu.N. 2014. The natural regeneration formation on the cutting areas in the conditions of the fresh hornbeam-oak forest in the southern part of the Ukraine Right-bank Forest-Steppe. Bulletin of KrasGAU, 2, 118-124. (In Russian).

Pasternak, P.S. (ed.). 1990. Forester's Reference. Kyiv, Urozhay, 295 pp. (In Russian).

Pyatnitskiy, S.S. 1933. Natural seed regeneration in Chuhuevo-Babchansky oak forest. Scientific papers of Chuhuguevo-Babchansky Forest Experimental Station, 1, 33-39. (In Russian).

Pyatnitskiy, S.S. 1968. Oak forests of Soviet Union, history and prospects of their further growth and increasing productivity. - Oak forests of Soviet Union and increasing their productivity. Kyiv, Urozhay, 7-27. (In Russian).

Romashov, N.V. 1973. Reforestation in different types of cuttings in oak forests of Left-bank Forest-Steppe of Ukrainian Soviet Socialist Republic. - Forestry and Forest Melioration, 32, 75-79. (In Russian).

Rumiantsev, M.G. 2016. Peculiarities of natural regeneration in moist fairly fertile maple-lime oak forest site type in the Left-bank ForestSteppe zone. - Proceedings of Ukrainian Scientific Conference of Young Scientists, Uman, Ukraine, May 2016. Kyiv, Osnova, 172174. (In Ukrainian).

Rumyantsev, M.G. 2015. Features of advance regeneration of tree species in dry maple-lime oak forest in the Left-bank Forest-Steppe. Forestry and Forest Melioration, 126, 92-98. (In Ukrainian).

Ryzhkov, O.V. 2001. Condition and development of oak stands of Central Forest-Steppe zone (in case of Central Black Earth and "Les na Vorskle" reserves). Tula, Nauka. 182 pp. (In Russian).

Sendonin, S.E. 2015. Age dynamics of natural oak reforestation amount under the ripening plantations shelter. - Scientific Herald of NULES of Ukraine. Series: Forestry and Decorative Gardening, 216(1), 72-77. (In Ukrainian).

Sevillano, I., Short, I., Grant, J., O’Reilly, C. 2016. Effects of light availability on morphology, growth and biomass allocation of Fagus sylvatica and Quercus robur seedlings. - Forest Ecology and Management, 374, 11-19.

Shevchenko, P.I. 1970. Natural (seed) regeneration in hornbeam forests of Podillya. -Ukrayinskyi lisovod, 10, 39-48. (In Ukrainian).

Sklyar, V.H. 2002. Ecological relationships of small advance growth of some broad-leaved species. - Ukrainian Botanical Journal, 59(5), 589-597. (In Ukrainian).

Sklyar, V.G., Dehtyaryov, V.M. 2013. Features of natural regrowth of dominate forest tree species in the "Retitska Dacha" array. - Bulletin of Sumy NAU, 3(25), 11-13. (In Ukrainian).

Sorogovets, P.E. 1958. Towards ecology of oak selfseeding. The effect of light on the growth and development. - Bulletin of Institute of Biology of Academy of Sciences of Belorussian Soviet Socialist Republic, 3, 28-34. (In Russian).

Tkach, V.P., Burnos, M.M., Haliv, M.A., Zyatkov L.L. 1996. Natural regeneration of floodplain forests in Left-bank Forest-Steppe zone of Ukraine and its use in forest cultivation. Forestry and Forest Melioration, 92, 27-35. (In Ukrainian).

Tkach, V.P., Luk'yanets, V.A., Kuprina, N.P., Rumyantsev, M.G. 2014a. The results of studies on weakened coppice oak stands reformation in the Left-bank Forest-Steppe of Ukraine. Forestry and Forest Melioration, 125, 72-78. (In Ukrainian).

Tkach, V.P., Luk'yanets, V.A., Rumyantsev, M.G. $2014 \mathrm{~b}$. Advance regeneration of tree species in fresh maple-lime oak forest of the Leftbank Forest-Steppe. - Forestry and Forest Melioration, 124, 47-54. (In Ukrainian).

Tkach, V.P., Rumyantsev, M.G., Chygrynets, V.P., Luk'yanets, V.A., Kobets, O.V. 2015. Features of natural seed regeneration in fresh maplelime oak forest in the Left-bank Forest-Steppe. - Forestry and Forest Melioration, 127, 43-52. (In Ukrainian).

Tkach, V.P., Rumiantsev, M.H., Luk'yanets, V.A., Lunachevskyy, L.S., Chyhrynets, V.P., Samoday, V.P. 2017. Oak forest stands in the North-East of Ukraine and features of their natural regeneration. - Forestry and Forest Melioration, 130, 77-85. (In Ukrainian). 
Vedmid, M.M., Zhezhkun, A.M., Poznyakova, S.I., Lukjanets, V.A. 2008. Previous renewal in forest stands of fresh oak groves in the Left-bank Ukraine. - Forestry and Forest Melioration, 112, 48-56. (In Ukrainian).

Vizoso-Arribe, O., Díaz-Maroto, I., Vila-Lameiro, P., Díaz-Maroto, M. 2014. Influence of the canopy in the natural regeneration of Quercus robur in NW Spain. Biologia, 69(12), 1678-1684. https:/ / doi.org/10.2478/s11756-014-0481-6.

Wiesner, J. 1879. Die heliotropischen Erscheinungen im Pflanzenreiche. Eine Physiologische Monographie. I. Theil. (Mit 1
Holzschnitt.). - Denkschriften der Akademie der Wissenschaften.Math.Natw.Kl. Frueher: Denkschr.der Kaiserlichen Akad. der Wissenschaften. Fortgesetzt: Denkschr.oest. Akad.Wiss.Mathem.Naturw.Klasse, 39_1, 143-209. [WWW document]. - URL http:// www.zobodat.at/pdf/DAKW_39_1_01430209.pdf. [Accessed 21 December 2018].

Zhukov, A.B. 1949. Oak forests of USSR and methods of their restoration. - Oak forests of USSR. Vol. 1. Moscow, Leningrad, Goslesbumizdat. 352 pp. (In Russian). 